\title{
ВОСПИТАНИЕ ПАТРИОТИЗМА (ИЗ ОПЫТА РАБОТЫ ПРЕПОДАВАТЕЛЯ)
}

\section{Источинская Елена Анатольевна} преподаватель

ГБОУ «Миасский машиностроительный колледж»

\begin{abstract}
Аннотация. В данной статье автором предпринята попытка представления и популяризации практического опыта воспитания чувства патриотизма у студентов колледжа средствами учебной деятельности по образовательным дисциплинам: информатика, математика, дискретная математика с элементами математической логики, теория вероятностей и математическая статистика, элементы математической логики.
\end{abstract}

Ключевые слова: воспитание патриотизма, великий бунтарь и новатор наук, ведущий алгебраист мира, полный по Тьюрингу язык.

\section{EDUCATION OF PATRIOTISM (FROM THE EXPERIENCE OF THE TEACHER)}

\section{Istochinskaya Elena Anatolyevna}

\begin{abstract}
In this article, the author attempts to generalize and popularize the practical experience of fostering a sense of patriotism among college students by means of educational activities in educational disciplines: computer science, mathematics, discrete mathematics with elements of mathematical logic, probability theory and mathematical statistics, elements of mathematical logic.

Key words: education of patriotism, great rebel and innovator of sciences, leading algebraist of the world, turing-complete language.

В настоящее время происходят преобразования современной образовательной системы, по-новому формулируются цели образования и воспитания. Для успешной социальной адаптации человека в современном обществе ему нужны не только глубокие научные знания, но и умения творчески применять их на практике, в повседневной жизни.
\end{abstract}


Воспитание патриотизма - это постоянная работа по созданию у студентов колледжа чувства гордости за своё Отечество, за своих соотечественников, уважение к их великим свершениям и достойным страницам прошлого как фундаменту нашего настоящего и наших будущих достижений.

На уроках математики, дискретной математики с элементами математической логики, теории вероятностей и математической статистики, информатики, элементов математической логики, излагая учебный материал, можно ярко и убедительно, не нарушая его логики, показать роль и преемственность патриотических традиций в становлении и развитии науки и техники.

Формирование у студентов чувства патриотизма на уроках учебных дисциплин общего естественнонаучного цикла, профессионального цикла начинается со знакомства обучающихся с биографией и достижениями ученых, внесших большой вклад в становлении и развитие российской и мировой науки, с историей изобретений и открытий в той или иной области знаний.

Изучение информатики, математики, теории вероятностей с элементами математической статистики, дискретной математики $\mathrm{c}$ элементами математической логики, даёт возможность уже с первых уроков знакомить студентов с именами русских учёных, советских учёных, наших соотечественников и современников, посвятивших свою жизнь служению Родине, России, познакомить обучающихся с достижениями российской науки.

Так, в ходе уроков по элементам математической логики, математике, теории вероятностей и математической статистики, дискретной математики с элементами математической логики учебный материал сопровождается знакомством студентов с биографиями великих ученых и их трудами:

— основоположник русской науки Михаил Васильевич Ломоносов,

- один из виднейших математиков первой половины XIX века Михаил Васильевич Остроградский, внёс большой вклад в алгебру, теорию чисел, теорию вероятностей, в прикладные аспекты математического анализа,

- великий бунтарь и новатор наук второй половины XIX века, гордостью русской науки и один из величайших математиков Европы Пафнутий Львович Чебышев, который сумел создать новые направления в 
разных областях: теории вероятностей, теории приближения функций многочленами, интегральном исчислении, теории чисел и т.д.,

— великий русский математик, профессор Казанского университета Николай Иванович Лобачевский, создавший новую геометрию в 20-х годах XIX века,

- достойная представительница славной когорты отечественных математиков Софья Васильевна Ковалевская, её труд «К теории дифференциальных уравнений в частных производных» излагается сейчас во всех книгах, посвященных этой области математики,

— гениальный математик Александр Михайлович Ляпунов, чей труд вошел во все учебники теории вероятностей и математической статистики,

- русский математик, педагог, автор первого печатного руководства "Арифметика " Леонтий Филиппович Магницкий,

- выдающийся ученый, одним из первооткрывателей логического моделирования дискретных и аналоговых устройств, русский логик Виктор Иванович Шестаков,

- русский математик Андрей Николаевич Колмогоров - автор ряда мировых открытий, создатель научной школы по теории вероятностей и теории функций, автор фундаментальных трудов по информатике, математической логике, теории множеств, теории интеграла, дифференциальным уравнениям, функциональному анализу, теории функций и, особенно, по теории вероятностей,

- советский ученый в области математики, механики, космической науки и техники, государственный деятель, организатор науки, Мстислав Всеволодович Келдыш, его работы по теории функций комплексного переменного и её приложений, работы по теории потенциала и гармоническим функциям, дифференциальным уравнениям и вычислительной математике принесли М. В. Келдышу международное признание как математику,

- Советский математик, кибернетик, Виктор Михайлович Глушков, ведущий алгебраист мира, ему принадлежит заслуга формирования нового понимания кибернетики как научной дисциплины со своей методологией и структурой исследований.

На уроках информатики при освоении учебного материала студенты знакомятся с биографией и трудами учёных-соотечественников, заложивших теоретическую основу вычислительной техники, стоявших у истоков разработки и создания советского компьютера: Ершов Андрей Петрович, 
Сергей Алексеевич Лебедев, Исаак Семенович Брук, Башир Искандарович Рамеев, Михаил Александрович Карцев, Николай Яковлевич Матюхин, Всеволод Сергеевич Бурцев и многих других.

Большинство студентов с трудом могут представить время, когда не было компьютеров и современных гаджетов.

На уроках информатики история создания компьютера изучается с повышенным интересом, тем более у студентов Миасского машиностроительного колледжа есть возможность работать на компьютерах на учебных занятиях и во внеурочное время, в библиотеке колледжа иметься разнообразная литература по вычислительной технике и сопряжённых с ней областями знаний, есть доступ в Интернет.

После полученных знаний в разделе «Информационная деятельность человека» по учебной дисциплине «Информатика» на многие события в истории Отечества студенты смотрят «по-другому».

Например: Советские ученые и инженеры создали первую цифровую электронную вычислительную машину в континентальной Европе, что существенно повлияло на мировое лидерство СССР в космосе.

Например: Вычислительная техника очень долго не рассматривалась государством как ключевой элемент развития, считалось, что это отрасль хотя и важная, но не имеющая самостоятельного значения, что стало одной из причин затяжного экономического спада и последующего политического развала СССР. Сегодня в России нет ни одной компании - производителя вычислительной техники, которая являлась бы значительным игроком на международном рынке, несмотря на то, что русские могут с полным правом утверждать, что были в числе пионеров в области развития вычислительных технологий.

На уроках Информатики также есть прекрасная возможность показать, какой ценой была завоевана Победа в Великой Отечественной войне, что непосильный, самоотверженный творческий труд ученых-математиков в годы войны можно назвать настоящим гражданским подвигом. Война показала, что советский человек в патриотическом порыве способен быстро и уверенно решать большие и трудные задачи. Победа Советской армии в Великой Отечественной войне была победой и советской науки.

При получении знаний в разделе «Прикладные программные средства» по учебной дисциплине «Информатика» студенты создавали презентации, посвященные 75-летию Победы нашего государства в Великой 
Отечественной войне, работали над проектами: «Лица Победы», «Снятие блокады Ленинграда», «Сталинградская битва» и другие.

Изучение темы «Непрерывные случайные величины» по учебной дисциплине «Теории вероятностей и математической статистики» неразрывно связано с именами гениальных математиков: Андреем Андреевичем Марковым, сформулировавшем и начавшем работать над доказательством центральной предельной теоремой теории вероятностей, и Александром Михайловичем Ляпуновым, доказавшем центральную предельную теорему теории вероятностей. Студенты делают сообщения, презентации по биографии и научным работам А.А. Маркова.

При освоении учебного материала раздела «Алгебра высказываний» учебная дисциплина «Элементы математической логики», студенты знакомятся с биографией и трудами Иосифа Нусимовича Бродского одного из основоположников символической логики в России и одного из основателей современной петербургской логической школы, Николаем Александровичем Васильевым - российским и советский философом, учёным и педагогом, предвосхитившим развитие системы воображаемой (неаристотелевой) и основных разделов современной неклассической логики, Иваном Ефимовичем Орловым - русским философом, предшественник релевантной и других подструктурных логик, пионер параконсистентного направления в логике.

Освоение учебного материала «Нормальные алгоритмы Маркова», «Принцип нормализации Маркова» раздела «Элементы теории алгоритмов» - учебная дисциплина «Элементы математической логики», основывается на трудах советского математика А.А. Маркова (младшего), которым введено понятие нормального алгоритма. Нормальный алгоритм Маркова - полный по Тьюрингу язык, что делает его по выразительной силе эквивалентным машине Тьюринга и, следовательно, современным языкам программирования. На основе нормального алгоритма Маркова был создан функциональный язык программирования Рефал.

В рамках внеаудиторной самостоятельной работы учебная дисциплина «Элементы математической логики» студенты готовили сообщения: «В.И. Шестаков и логическое моделирование», «А.А. Марков основоположник советской школы конструктивной математики», «Вклад П.С. Новикова в математическую логику». 
На ставшем традиционном ежегодном внеклассном мероприятии, посвященному дню математика - 1 апреля, студенты готовят проекты, готовят информационные листы о русских и советских учёных-математиках, о математиках-основоположниках советских вычислительных машин, математиках - наших современниках, составляющих гордость современной Российской и мировой науки: Григорий Яковлевич Перельман, который доказал несколько ключевых утверждений в Александровской геометрии пространств ограниченной снизу кривизны; в 1994 году доказал гипотезу о душе в дифференциальной геометрии; в 2002-2003 годах доказал гипотезу Пуанкаре и гипотезу геометризации.

Самостоятельная внеаудиторная работа по учебным дисциплинам предполагает создание студентами презентаций, сообщений, информационных листов ко дню Конституции Российской Федерации, дню защиты детей, дню молодёжи, дню народного единства, дню космонавтики, по памятным датам Великой Отечественной войны и так далее.

В 2019-2020 годах студенты принимали участие в Едином уроке безопасности в сети Интернет, в цифровом диктанте - Всероссийской образовательной акции по определению уровня цифровой грамотности.

Bce это, по нашему убеждению, способствует формированию и развитию личности гражданина - патриота России, способного соединить патриотические чувства и патриотическое самосознание с идеалом гражданственности, ценностями социальной солидарности, справедливости, ответственности, готового служить российскому обществу и укреплению его единства, сознающего все значение единства российского общества, важность и ценность общероссийской идентичности.

«Если не давать ребенку покоя и с утра до ночи что-то ему вдалбливать, он на всю жизнь останется унылым и безрадостным».

Лев Давидович Ландау, лауреат Нобелевской премии.

\section{Список литературы}

1. Буторина Т.С. Воспитание патриотизма средствами образования / Буторина Т.С., Н.П. Овчинникова // - СПб: КАРО, 2004. - 224 с. 
2. Воспитательная деятельность педагога: Учебное пособие/ И.А.Колесникова, Н. М. Борытко, С. Д. Поляков, Н. Л. Селиванова; под общ. Ред. В. А. Сластенина и И. А. Колесниковой //- М., «Академия», 2015. с.166

3. Гасанов, 3.Т. Цель, задачи и принципы патриотического воспитания граждан / 3.Т. Гасанов // Педагогика. - 2005. - №6. - С. 59-63.

4. «Об образовании в Российской Федерации» Федеральный закон от 29 декабря 2012 г. №273-ФЗ. М. Издательство ООО «ТЦ Сфера».2014.

5. Овчинникова, Н.П. Идея патриотизма и Отечества в истории русской педагогики / Н.П. Овчинникова // Педагогика. - 2007. - №1 . - С. 93 101

6. Стратегия развития воспитания в Российской Федерации на период до 2025 года. Распоряжение Правительства Российской Федерации от 29 мая 2015г. N 996-р г. Москва.

() Е.А. Источинская, 2020 